\title{
High-Glucose and Free Fatty Acid-Induced Adipocytes Generate Increasing of HMGB1 and Reduced GLUT4 Expression
}

\author{
Rita Rosita $^{1 *}$, Yuyun Yueniwati ${ }^{2}$, Agustina Tri Endharti ${ }^{3}$ iD, Mochamad Aris Widodo ${ }^{4}$ (D)
}

${ }^{1}$ Department of ??? Brawijaya University, Malang, Jawa Timur, Indonesia; ${ }^{2}$ Department of Radiology, Universitas Brawijaya, Malang, Jawa Timur, Indonesia; ${ }^{3}$ Department of Parasitology, Faculty of Medicine, Brawijaya University, Malang, Jawa Timur, Indonesia; ${ }^{4}$ Department of Clinical Pharmacology, Faculty of Medicine, Brawijaya University, Malang, Jawa Timur, Indonesia

Edited by: Sinisa Stojanosk Citation: Rosita R, Yueniwati Y, Endharti AT, Widodo MA. High-Glucose and Free Fatty Acid-Induced Adipocytes Generate Increasing of HMGB1 and Reduced GLUT4 23; 9(A): $1258-1264$ Adipocytes; High Glucose; FFA: Necrotic Cell Keywords: Adipocytes; High Glucose; FFA; Necrotic Cel
Death; Hypertrophy; Insulin Resistance *Correspondence: Rita Rosita, Brawijaya University. Malang, Jawa Timur, Indonesia. E-mail: ritafkub11@gmail.com Received: 02-Sep-202 Revised: 11-Nov-202 Accepted: 13-Nov-202 Copyright: ๑ 2021 Rita Rosita, Yuyun Yueniwati, Agustina Tri Endharti, Mochamad Aris Widodo not receive any financia Competing Interest: The authors have declared that no competing intere Open Access: This is an open-access article distribute under the terms of the Creative Commons AttributionNonCommercial 4.0 International License (CC BY-NC 4.0)

\section{Introduction}

Development of insulin resistance in adipose tissue is closely associated with adipocyte hypertrophy and pro-inflammatory responses. However, it is not yet known whether hypertrophy per se as triggers or through an inflammatory cascade might be sufficient to provoke insulin resistance in adipose tissue. Adipocytes hypertrophy is the main cause of energy metabolic system dysfunction, obesity, and its afflictions such as T2D [1]. Chronic excess nutrient-induced adipose tissue expansion leads to lipid droplets (LDs) hypertrophy [2], [3], and when its fully lipid-engorged, stress signals will be raised. Highmobility group box 1 (HMGB1), a non-histone chromatinbinding protein, released from predominate necrosis adipocytes on stressful insults [4]. Extracellular HMGB1 acts as an innate alarmin to stimulate the activation of resident immune cells in the adipose tissue and exhibits inflammatory responses in T2D [5].

Adipocyte death in obesity is likely to be the dominant necrosis form [6] indicated by increased level of HMGB1 [7] and cellular features of necrosis, including ruptured plasma membranes, dilated endoplasmic reticulum, cell debris in the extracellular space, and the appearance of small LDs in the cytoplasm [8], [9]. In an experimental animal model, high-level HMGB1 is associated with hyperglycemia [10], and high-fat diet-induced obesity [11]. In vitro studies on adipocytes have shown that distribution of HMGB1 in lean and obese normoglycemic individuals has predominantly nuclear while in obese patients with type 2 diabetes have localized to the cytosol [12]. HMGB1 release from adipocytes has studied with LPS as inflammation triggered [13]. However, according to our knowledge, no studies have been undertaken to investigate HMGB1 release with nutrient as trigger in relation to adipose tissue function in insulin-resistant states.

Glucose and FAs are transported into adipocytes through specific transporter molecules that insert into the cell membrane in response to insulin. GLUT4 is the main insulin-responsive glucose transporter in adipocytes [14], but there are also insulin-independent mechanisms for cellular GLUT4 translocation and glucose uptake [15]. Cluster of differentiation 36 is used as the fatty acid translocase 
responsible for transportation of FAs across the adipocyte plasma membrane to be utilized or as energy storage [16]. The previous studies have determined that increasing fatty acid uptake of adipocytes requires greater synthesis triglycerides (TGs) in LDs, and this can lead to ER stress activating the JNK pathway, thus further increasing insulin resistance [17]. High glucose also induces adipose inflammation and insulin resistance through JNK activation [18]. Therefore, it would be very interesting to know the HMGB1 extracellular level and cellular appearance of adipocytes after affected by elevated glucose and FFA levels.

To develop successful strategies to treat obesity and T2D, studies using hypertrophic adipocytes models that adequately mimic the aspects of obesity are needed. Regarding to this, we exposed differentiated adipocytes to long-chain FFA and/or high-glucose concentration. The aim of this study was to compare the effect of highglucose, high-fat, or a combination of both on primary rat adipocytes, and determine the correlation of adipocytes size with cellular GLUT4 and necrotic adipocytes death. We hypothesized that there is different HMGB1 level and adipose tissue function in insulin-resistant states of each treatment group. We instead demonstrate decreased cellularity of adipocytes in high-glucose exposed cells, along with breakdown LDs into small multilocular LDs in FFA-exposed cells. Our findings support a hypertrophic model of primary rat adipocytes cultures in which metabolically impaired from HG + FFA-exposed cells.

\section{Material and Methods}

\section{Cells cultures of stromal vascular fraction}

Healthy non-obese Wistar rats (4-5 weeks old) were sacrificed and submerged in $70 \%$ ethanol for 2 min. Adipose tissue was collected from peritoneal and retroperitoneal regions [19]. Fat tissue was removed and digested enzymatically by type 1 collagenase (Worthington), $1 \mathrm{mg}$ in $7 \mathrm{ml}$ Dulbecco's Modified Eagle Medium (DMEM) for 20 min at $37^{\circ} \mathrm{C}$ in a shaking bath. The cell suspension was filtered followed by centrifugation (1500 rpm for $7 \mathrm{~min}$ ). The obtained cells were maintained in a culture flask and nourished using DMEM containing sodium bicarbonate, L-glutamine, antibiotics (100 U/ml) penicillin, and $100 \mathrm{mg} / \mathrm{ml}$ streptomycin (MP Biomedical, LCC), and supplemented with $10 \%$ of heat-inactivated fetal bovine serum $\left(\mathrm{Gibco}^{\odot}\right)$. Adipocyte culture was kept at $37^{\circ} \mathrm{C}, 5 \% \mathrm{CO}_{2}$. Media were changed every 2 days.

\section{Fatty acids and high-glucose} supplementation

Confluent cultures were maturated by $0.1 \mu \mathrm{M}$ dexamethasone, $0.5 \mathrm{mM}$ isobutylmethylxanthine, and
$0.1 \mu \mathrm{M}$ insulin [19] and subcultured at a density of $0.05 \times 10^{6} \mathrm{cells} / \mathrm{ml} /$ well in 24 -well culture plates in growth . Cells cultures were exposed to 5 or $25 \mathrm{mmol} / \mathrm{l}$ glucose with or without $250 \mu \mathrm{mol} / / \mathrm{l}$ palmitic acids (16:0) with daily replenishment for 7 days. At the time of harvesting cells (day 7 or 9), oil red $\mathrm{O}$ staining was performed according to Krauss, 2016, as described [20]. The degree of adipogenic differentiation was determined by extracting the dye from stained cells with $750 \mu$ of isopropanol and then measured the absorbance at $500 \mathrm{~nm}$ [21].

\section{Cell size quantification}

Cell size was determined by microscopic measurement of cell diameter (Nikon Eclipse TE 2000-U and Q-Capture Suite 2.66.4.0, Quantitative Imaging Corp). Cell diameter was measured using ImageJ version 1.47 (National Institutes of Health, USA). A total number of 100 adipocytes were measured from each treatment group of cells. Cells $<10 \mu \mathrm{m}$ were excluded from analysis [22].

\section{GLUT4 immunofluorescence staining}

The immunofluorescence staining was performed for analysis of GLUT4 in adipocytes. Coverslips containing cells were fixed for $5 \mathrm{~min}$ in $75 \%$ acetone $25 \%$ ethanol. Subsequently, sections were washed 3 times for 5 min in phosphate-buffered saline (PBS, $137 \mathrm{mmol} / \mathrm{L}$ sodium chloride, $3 \mathrm{mmol} / \mathrm{L}$ potassium chloride, $8 \mathrm{mmol} / \mathrm{L}$ sodium phosphate dibasic, and 3 $\mathrm{mmol} / \mathrm{L}$ potassium phosphate monobasic). GLUT4 antibody (rat $\operatorname{lgG}$, Santa Cruz) was applied to the sections at a dilution of $1: 200$ in $5 \%$ normal serum (NGS, Invitrogen) for $2 \mathrm{~h}$ at room temperature. The antibody used binds the cytosolic C terminal of GLUT4 to visualize intracellular GLUT4. Following primary antibody, incubation sections were washed 3 times for 5 min in PBS. DAPI (Sigma-Aldrich) staining for cell nuclei was added to the secondary antibody at a $0.5 \mu \mathrm{g} \cdot \mathrm{mL}^{-1}$ concentration. After secondary antibody, incubation sections were washed 3 times for $5 \mathrm{~min}$ in PBS and coverslips were mounted with $20 \mu \mathrm{L}$ mowiol; $6 \mathrm{~g}$ glycerol (Sigma-Aldrich), $2.4 \mathrm{~g}$ mowiol 4-88 (Sigma-Aldrich), and $0.026 \quad g$ 1,4-diazobicyclo-[2,2,2]-octane (Sigma-Aldrich) dissolved in $18 \mathrm{~mL} 0.2 \mathrm{~mol} / \mathrm{L}$ Tris-buffer (pH 8.5) (Sigma-Aldrich). Quantitation of GLUT4 using image processing and analysis was carried out in Fiji-win 32 and was kept consistent between images. GLUT4 fluorescence intensity was quantified by measuring the signal intensity within the intracellular. Intracellular spot number and staining area were quantified by setting uniform threshold intensity and size values to identify spots within intracellular regions [23].

\section{Measurement of HMGB1 extracellular level}

The HMGB1 supernatant concentrations were determined with a recently established available ELISA 
kit (BT-Lab E1635Hu). Briefly, in the wells coated with anti HMGB1 monoclonal antibody, samples to be measured and standards were incubated for $24 \mathrm{~h}$ at $37^{\circ} \mathrm{C}$. After washing the wells for 5 times, a peroxidase-conjugated anti-HMGB1 monoclonal antibody was added into the microwells and incubated for $120 \mathrm{~min}$ at room temperature. After washing the wells for 5 times, $100 \mathrm{uL}$ of substrate solution was added and incubated for 30 min at room temperature. A stop solution was added, and the absorbance was measured at $450 \mathrm{~nm}$ using microplate reader. The concentrations of the samples were then calculated from the standard curve [24].

\section{Statistical analyses}

Results are presented as mean \pm SEM. Statistical significance was determined using Manova and post hoc Bonferroni tests. Differences were considered significant with $p<0.05$ using SPSS 20.0 software. A Q-Q plot with observed picture the Mahalanobis distances used to evaluate (subjectively) data may have a multivariate normal distribution ( $q \mathrm{i}=1$ ).

\section{Results}

\section{differentiation \\ Characterization of adipocyte}

Wistar rat primary pre-adipocytes were differentiated into adipocytes and the pure adipocyte fractions were assessed by monitoring morphologically and oil red $\mathrm{O}$ staining (Figure $1 \mathrm{a}$ and $\mathrm{b}$ ). The efficacy of differentiation reached approximately 90-95\%, indicating that adipocytes could be considered as a specific homogenous cell type. As depicted in Figure 1a, no LD was observed in pre-adipocytes. Conversely, adipocytes were occupied by either medium-sized or single large LDs (Figure 1b).

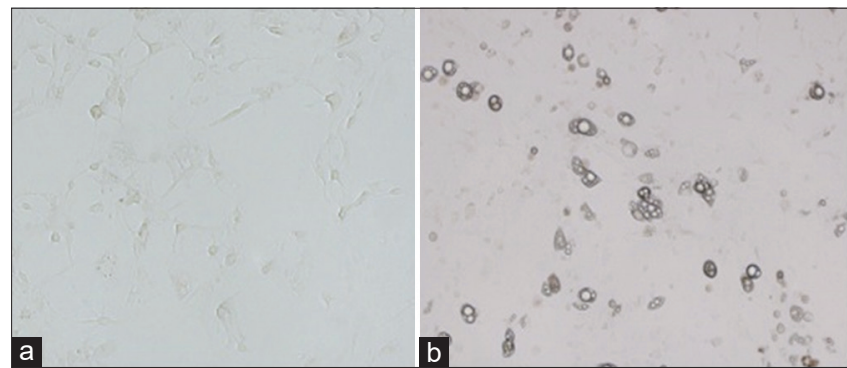

Figure 1: Differentiation of visceral pre-adipocytes to adipocytes. (a) Confluence pre-adipocytes (no lipid droplets [LDs]) were reached on day 3 of perfusion culture with the DMEM and (b) adipocytes (with medium-sized or single large LDs) following differential factor contained insulin perfusion, the cells exhibited morphological changes characteristic of adipogenic differentiation, assuming a rounded shape and forming lipid inclusion bodies visible as microscopic droplets

\section{Combination high-glucose and FFA exposure generate adipocytes hypertrophy}

To mimic a condition of chronic energy excess, we exposed adipocytes to high-glucose concentration and FFA. In this study, adipocytes in control group were occupied by either medium-sized to large-sized unilocular LDs, however, with addition of FFA daily replenishment of medium, there was a slight decrease in size, but have small multiple LDs (Figures 1 and 2). The results that are not surprising are cells with combination $H G$ + FFA exposures that have a significant increase in cell size (hypertrophy) with large unilocular droplet (Figure 2a and 3). Comparing the two previous results, the FFA studied has divergent effects on adipogenesis.

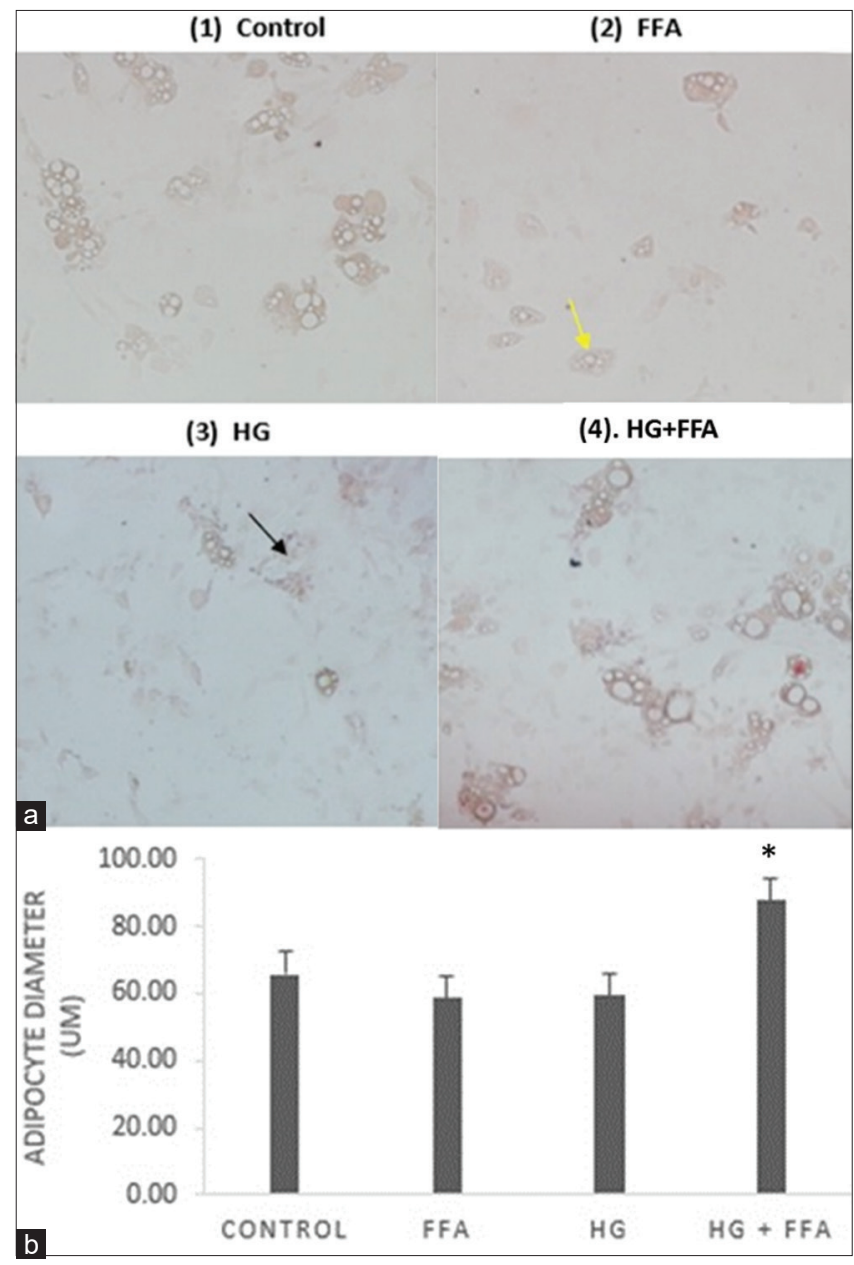

Figure 2: (a) Adipocytes appearance after treatment was visualized with oil red $O$ staining (magnitude $\times 10)$. The treatment gives a different effect on cell size, the greatest is combination HG + FFA exposures (A4). Cells with FFA and HG exposures almost have the same size, but different cellular appearance. Cells density of $H G$ exposures (A3) is low and comes into view cell shedding (black arrow). FFA cells (A2) appear to be predominantly multilocular lipid droplets (yellow arrow). (b) Adipocytes diameter. Cells with combination HG + FFA have greatest size compared the other cells groups $(p<0.05)$

The moststriking observation to emerge from the cell appearance comparison was high-glucose exposed adipocytes appear to have a small size with unclear cell boundaries, indicate the possibilities of necrotic cell 


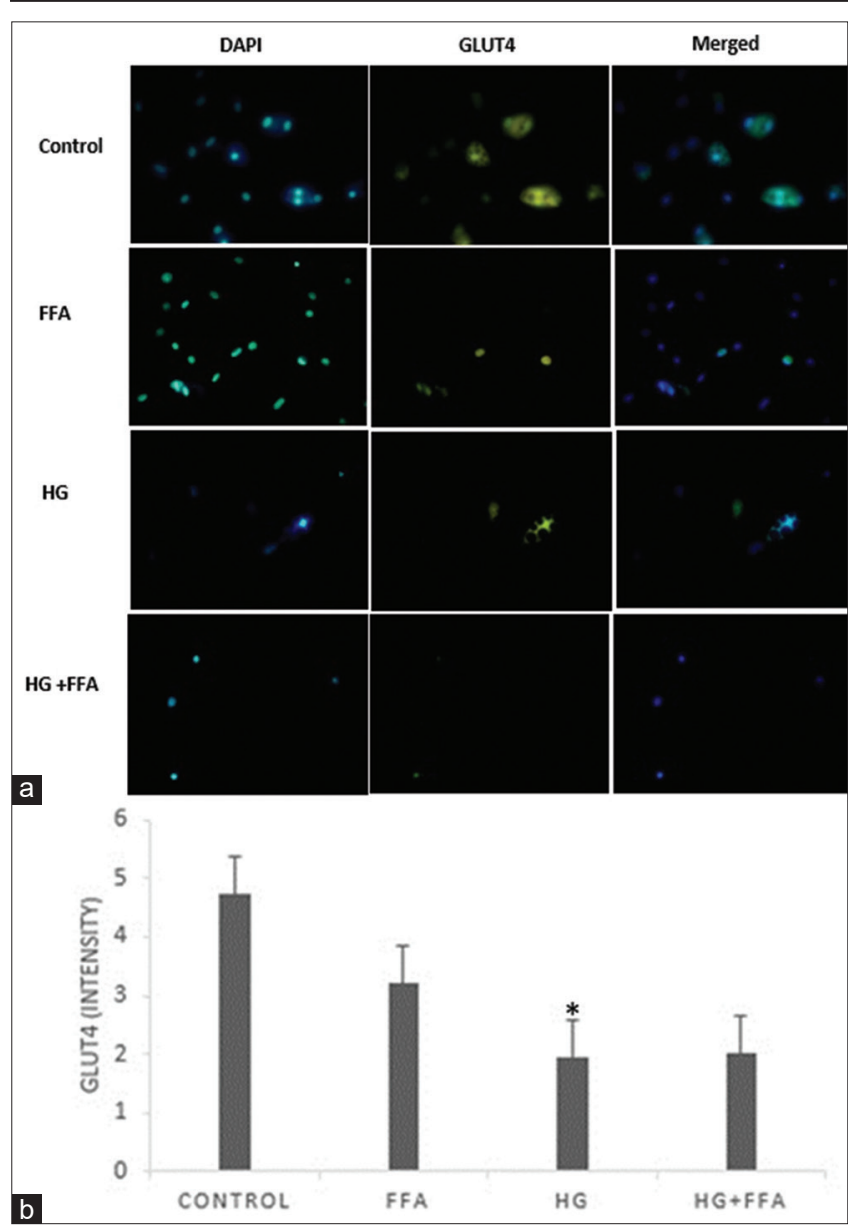

Figure 3: ( $a$ and b) High glucose suppresses total GLUT4 expression $(p<0.05)$. FFA and combination of $H G+$ FFA decrease total GLUT4 expression but no significance differences $(p>0.05)$. Total Glut4 was analyzed using anti-GLUT4 followed by fluorescein isothiocyanate-labeled secondary antibody (magnitude $\times 400$ ) stained in combination with DAPI (blue) to mark the cell nuclei

death. There were cells with very small droplet lipids, or even none at all just like pre-adipocytes, exhibit that high-glucose disrupted adipocytes differentiation process or adipogenesis (Figures 2a and 4).

\section{High-glucose and FFA induce increasing of HMGB1 level on adipocytes}

Since the release of the chromatin protein high-mobility group B1 (HMGB1) is a biomarker of necrotic cell death (Yang et al., 2014), to evaluate the effect of high glucose and FFA exposure on necrotic cell death, we used MANOVA test to analyze the different levels of extracellular HMGB1 in each group. Levels of HMGB1 in high-glucose and FFA exposure group increased significantly compared to controls $(p<$ $0.05)$. From the graphic in Figure 4 , a quite surprising result was the level of HMGB1 on combination HG + FFA exposures which was almost similar as the control $(p>0.05)$. Further statistical tests revealed that there was a significant negative correlation between cell size and HMGB1 level (Pearson's correlation coefficient, $r=-0.637, p=0.026)$.

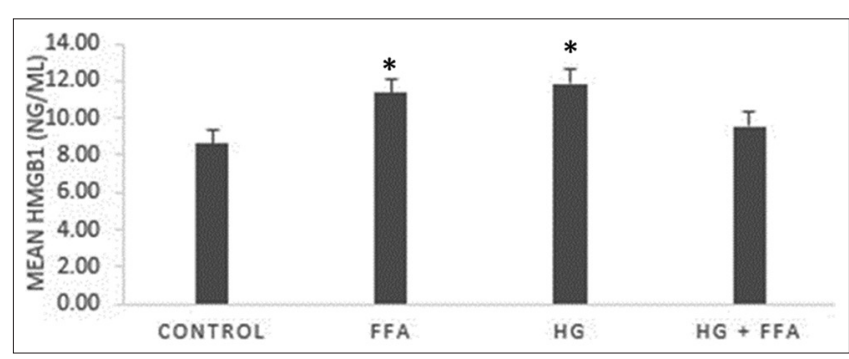

Figure 4: High-mobility group box 1 protein (HMGB1) release into the media from treated cells group. HG and FFA exposure cells increase HMGB1 level significantly than control $(p<0.05)$, rather than cells with combination HG + FFA exposures that increase slightly than control $(p>0.05)$

\section{High-glucose-induced insulin resistance on adipocytes}

After $7 \mathrm{~h}$ exposure of rat adipocytes to high glucose, we observed a significant reduction in total GLUT4 relative compare to control $(p<0.05)$ (Figure 3 ) with impairment of adipogenesis, marked by the small size of the adipocytes and damaged cells (Figure 2). However, there was no significant difference between control cells and FFA (palmitic-exposed cells) or HG + FFA with respect to insulin-induced glucose transport.

\section{Discussion}

The present study was designed to determine the effect of overnutrition that mimic of metabolic mileu that promotes obesity and insulin resistance on visceral adipose tissue. Adipocyte enlargement is a key feature of obesity and associated with insulin resistance and metabolic disease, characterized by large and unilocular LDs [25]. High-glucose concentration and/or FFA were exposed to primary differentiated adipocytes for 7 days. Our findings indicate that high-glucose-induced adipocytes necrotic cell death, showed by increased levels of extracellular HMGB1, released by damaged cells [26]. This includes the alteration of morphologic cells, there were unclear plasma membrane border, cell shedding, and blebbing. Obesity-associated adipocyte death represents necrosis trait, such as ruptured plasma membranes, dilated endoplasmic reticulum, cell debris in the extracellular space, and the appearance of small LDs in the cytoplasm and release HMGB1 into the extracellular space [4]. Hyperglycemia is defining metabolic disruption to adipocytes that can be considered as a nutrient stress condition [27]. ER stress may be perturbed by high-glucose conditions to contribute to adipocyte dysfunction such as insulin resistance, caused by increasing advanced glycation end-products formation leading to limit insulin signaling [28]. In this study, high glucose was found to supress GLUT4 expression to the lowest level compared to others. These results are consistent with those of other studies 
and suggest that GLUT4 defects in adipose tissue are early signs of metabolic alterations [29].

We found that high-glucose exposed caused cells damage whereas in the previous studies its revealed hypertrophy due to burst of the anabolic metabolism under chronic positive energy balance [30]. There are several possible explanations for this result, differentiated adipocytes are no need high-glucose supply after differentiation, proceed normally at 4 $\mathrm{mM}$. They are only need high-glucose pulse only 3 days in early differentiation phase [31]. Prolonged high-glucose exposure (7 days after differentiation), cells undergo nutrient stress and impair endoplasmic reticulum (ER) function, and activate the unfolded protein response [32]. Cells type differences can also caused this discrepancy. The previous study used 3T3-L1 adipocyte that potentially modulates its cell survival genes during differentiation contributing to resistance to cell death [33].

Comparison of FFA and high glucose, combination high-glucose and FFA-exposed cells yield some surprising findings. For example, while FFA (palmitic acids) and high glucose both increased HMGB1 extracellular level and showed morphologic characteristic of damaged cells, however, the combination of high glucose and FFA in the similar dose becomes hypertrophy with low HMGB1 level and GLUT4 expression. The reason for this discrepancy is still unclear but could represent that palmitate have divergent effects on adipogenesis. The size increase of adipocytes is dependent on diet. On the other hand, the diet-induced number increase of fat cells is dependent on strain, suggesting a synergy between genetics and diet [34]. Hypertrophy occurs to meet the need for additional fat storage capacity in the progression of obesity. Highfat high-glucose intake indeed exhibits increased LD hypertrophy, these result from the excessive storage of energy in the form of TGs in LDs which link to obesity and to insulin resistance [1]. Therefore, high-fat highglucose intakes can be developed into a hypertrophic cell model to study the effects and treatment of obesity.

We demonstrate that high FFA (palmitate $25 \mu \mathrm{mol}$ )-exposed adipocytes for 7 days lead to multilocular LDs and release of nuclear HMGB1 that frequently used as a marker of necrosis in sites of sterile inflammation. Multilocular adipocytes could derived from proliferation of precursor cells that already existed whether new mitochondria contained in them were typical brown adipocyte or unilocular adipocytes underwent conversion to multilocular mitochondria-rich adipocytes [35] or breakdown caused by cell damage. There are small proportion multilocular adipocytes (8\%) in WAT with positive UCP1 that typical for BAT [35]. Fatty acid particularly palmitic acid could activate brown adipose tissue mitochondria uncoupling protein [36]. This has to be proven by further cell morphology analysis with electron microscopy or biochemical analyses. LD morphology is closely related to the functions and characteristics of adipose tissues. Small multilocular LDs formation is ideal for the subsequent facilitation of FFA transport to mitochondria that are adjacent to LDs for $\beta$-oxidation leading to efficient intracellular lipolysis in BAT [37]. The browning of adipose tissue leads to enhanced energy expenditure and the prevention of obesity, clarification of the mechanism how administration of fatty acids in low-glucose conditions can convert WAT into BAT is very meaningful. However, this is confused with the elevation of HMGB1 level in the FFA-exposed cells. HMGB1 passively released from necrotic cells, enhancement of extracellular HMGB1 decreased autophagy that is vital to maintain cellular homeostasis and protect against inflammation of adipocyte injury after 4 days treatment [38]. LDs appear as regulator of cellular metabolism and play roles in the cellular stress response such as lipid overload [39]. Accumulation of reactive oxygen species due to functional impaired of mitochondria suspected as the cause of FFA-mediated necrosis [40] and the LDs tightly associate with mitochondria both morphologically and biochemically [41].

One unanticipated finding was that total GLUT4 in FFA-exposed cells did not decrease significantly, even had the lowest TNF $\alpha$ levels compared to other groups (data not shown). Another possible explanation for this is palmitate-induced lipophagy [42]. LDs are broken down by two major mechanisms: Lipolysis and lipophagy [27]. The present small multilocular LDs in FFA-exposed adipocytes indicate lipophagy, whereby parts or whole LDs are engulfed within autophagosomal membranes and fused with lysosomes for degradation by hydrolytic enzymes [43], suggesting how LD structure and dynamics define the multitude of their functions. Referring to the evidence that extracellular HMGB1 suppress autophagy, it can be assumed that the induction lipophagy by palmitate can reduce interference autophagy by HMGB1. Transcriptional factor that plays a role in lipophagy is peroxisome proliferator-activated receptor (PPAR)- $\gamma$ coactivator $1 \alpha($ PGC- $1 \alpha)$ and PPAR- $\alpha$ target genes involved in fat and glucose metabolism, and cellular proliferation and differentiation [44]. In liver, palmitate appears to upregulate PPAR $\gamma$ through PGC1 $\alpha$ [43]. However, more research on this topic needs to be undertaken before the association between FFA intake and HMGB1 release is more clearly understood.

\section{Conclusion}

The expression level studies between high glucose, FFA, and a combination of both on adipocytes results strongly suggest that high glucose is more 
induce adipocytes to release HMGB1, and reduced GLUT4 expression in adipocytes compared to FFA, and combination of both. Nevertheless, hypertrophic adipocytes which are one of characteristic signs of adipocytes dysfunction occur in high-glucose + FFAexposed cells.

\section{Acknowledgment}

This paper and the research behind it would not have been possible without the exceptional support of my early supervisor, Edi Widjajanto. His enthusiasm, knowledge, and exacting attention to detail have been an inspiration and kept my work on track.

\section{References}

1. Sanjabi B, Dashty M, Özcan B, Akbarkhanzadeh V, Rahimi M, Vinciguerra $M$, et al. Lipid droplets hypertrophy: A crucial determining factor in insulin regulation by adipocytes. Sci Rep. 2015;5:8816. https://doi.org/10.1038/srep08816 PMid:25743104

2. Muir LA, Neeley CK, Meyer KA, Baker NA, Brosius AM, Washabaugh AR, et al. Adipose tissue fibrosis, hypertrophy, and hyperplasia: Correlations with diabetes in human obesity. Obesity (Silver Spring). 2016;24(3):597-605. https://doi. org/10.1002/oby.21377

PMid:26916240

3. Meln I, Wolff G, Gajek T, Koddebusch J, Lerch S, Harbrecht L, et al. Dietary calories and lipids synergistically shape adipose tissue cellularity during postnatal growth. Mol Metab. 2019;24:139-48. https://doi.org/10.1016/j.molmet.2019.03.012 PMid:31003943

4. Zhang J, Zhang L, Zhang S, Yu Q, Xiong F, Huang K, et al. HMGB1, an innate alarmin, plays a critical role in chronic inflammation of adipose tissue in obesity. Mol Cell Endocrinol. 2017;454:103-11. https://doi.org/10.1016/j.mce.2017.06.012 PMid:28619625

5. Wang Y, Zhong J, Zhang X, Liu Z, Yang Y, Gong Q, et al. The role of HMGB1 in the pathogenesis of Type 2 diabetes. J Diabetes Res. 2016;2016:2543268. https://doi.org/10.1155/2016/2543268 PMid:28101517

6. Wagner M, Bjerkvig R, Wiig H, Dudley AC. Loss of adipocyte specification and necrosis augment tumor-associated inflammation. Adipocyte. 2013;2(3):176-83. https://doi. org/10.4161/adip.24472

PMid:23991365

7. Wang H, Qu H, Deng H. Plasma HMGB-1 levels in subjects with obesity and Type 2 diabetes: A cross-sectional study in China. PLoS One. 2015;10(8):e0136564. https://doi.org/10.1371/ journal.pone.0136564 PMid:26317615

8. Cinti S, Mitchell G, Barbatelli G, Murano I, Ceresi E, Faloia E, et al. Adipocyte death defines macrophage localization and function in adipose tissue of obese mice and humans.J Lipid Res. 2005;46(11):2347-55. https://doi.org/10.1194/jlr.

\section{M500294-JLR200}

PMid: 16150820

9. Sun K, Kusminski CM, Scherer PE. Adipose tissue remodeling and obesity. J Clin Invest. 2011;121(6):2094-101. https://doi. org/10.1172/JCl45887

PMid:21633177

10. Hagiwara S, Iwasaka H, Hasegawa A, Koga H, Noguchi T. Effects of hyperglycemia and insulin therapy on high mobility group box 1 in endotoxin-induced acute lung injury in a rat model. Crit Care Med. 2008;36(8):2407-13. https://doi.org/10.1097/ CCM.0b013e318180b3ba

PMid:18596634

11. de Souza AB, Chírico MT, Cartelle CT, de Paula Costa G, Talvani A, Cangussú SD, et al. High-fat diet increases HMGB1 expression and promotes lung inflammation in mice subjected to mechanical ventilation. Oxid Med Cell Longev. 2018;2018:7457054. https://doi.org/10.1155/2018/7457054 PMid:29619146

12. Guzmán-Ruiz R, Ortega F, Rodríguez A, Vázquez-Martínez $R$, Díaz-Ruiz A, Garcia-Navarro $S$, et al. Alarmin high-mobility group B1 (HMGB1) is regulated in human adipocytes in insulin resistance and influences insulin secretion in $\beta$-cells. Int $J$ Obes (Lond). 2014;38(12):1545-54. https://doi.org/10.1038/ ijo.2014.36 PMid:24577317

13. Gunasekaran MK, Viranaicken W, Girard AC, Festy F, Cesari M, Roche $\mathrm{R}$, et al. Inflammation triggers high mobility group box 1 (HMGB1) secretion in adipose tissue, a potential link to obesity. Cytokine. 2013;64(1):103-11. https://doi.org/10.1016/j. cyto.2013.07.017 PMid:23938155

14. Olson AL. Regulation of GLUT4 and insulin-dependent glucose flux. ISRN Mol Biol. 2012;2012:856987. https://doi. org/10.5402/2012/856987

PMid:27335671

15. Govers R. Molecular mechanisms of GLUT4 regulation in adipocytes Diabetes Metab. 2014;40(6):400-10. https://doi. org/10.1016/j.diabet.2014.01.005

PMid:24656589

16. Haczeyni F, Bell-Anderson KS, Farrel GC. Causes and mechanisms of adipocyte enlargement and adipose expansion. Obes Rev. 2018;19(3):406-20. https://doi.org/10.1111/obr.12646 PMid:29243339

17. Sears $B$, Perry $M$. The role of fatty acids in insulin resistance. Lipids Health Dis. 2015;14:121. https://doi.org/10.1186/ s12944-015-0123-1

PMid:26415887

18. Sorisky A. Effect of high glucose levels on white adipose cells and adipokines-fuel for the fire.Int J Mol Sci. 2017;18(5):944. https://doi.org/10.3390/ijms18050944

PMid:28468243

19. Aswaty N, Ratnawati R, Lyrawati D. Catechins of GMB-4 clone inhibits adipogenesis through PPAR- $\gamma$ and adiponectin in primary culture of visceral preadipocyte of rattus norvegicus wistar. Res J Life Sci. 2018;5(1):54-65. https://doi.org/10.21776/ ub.rjls.2018.005.01.6

20. Kraus NA, Ehebauer F, Zapp B, Rudolphi B, Kraus BJ, Kraus D. Quantitative assessment of adipocyte differentiation in cell culture. Adipocyte. 2016;5(4):351-8. https://doi.org/10.1080/21 623945.2016 .1240137

PMid:27994948

21. Chu DT, Malinowska E, Gawronska-Kozak B, Kozak LP. Expression of adipocyte biomarkers in a primary cell culture models reflects preweaning adipobiology. J Biol 
Chem. 2014;289(26):18478-88. https://doi.org/10.1074/jbc. M114.555821

PMid:24808178

22. Parlee SD, Lentz SI, Mori H, MacDougald OA. Quantifying size and number of adipocytes in adipose tissue. Methods Enzymol. 2014;537:93-122. https://doi.org/10.1016/ B978-0-12-411619-1.00006-9

PMid:24480343

23. Bradley H, Shaw CS, Worthington PL, Shepherd SO, Cocks M, Wagenmakers AJ. Quantitative immunofluorescence microscopy of subcellular GLUT4 distribution in human skeletal muscle: Effects of endurance and sprint interval training. Physiol Rep. 2014;2(7):e12085. https://doi.org/10.14814/phy2.12085 PMid:25052490

24. Sasaki D, Mitchell R. How to Obtain Reproducible Quantitative ELISA Results, Oxford Biomedical! Research, Oxford MI No. 48371; 2001. Available from: https://www.oxfordbiomed. $\mathrm{com} / \mathrm{sites} /$ default/files/2017-02/how\%20to\%20obtain $\% 20$ reproducible $\% 20$ quantitative\%20 elisa\%20results.pdf. [Last accessed on 2021 May 20].

25. Kim JI, Huh JY, Sohn JH, Choe SS, Lee YS, Lim CY, et al. Lipidoverloaded enlarged adipocytes provoke insulin resistance independent of inflammation. Mol Cell Biol. 2015;35(10):1686-99. https://doi.org/10.1128/MCB.01321-14

PMid:25733684

26. Yang $M$, Antoine DJ, Weemhoff JL, Jenkins RE, Farhood A, Park BK, et al. Biomarkers distinguish apoptotic and necrotic cell death during hepatic ischemia/reperfusion injury in mice. Liver Transpl. 2014;20(11):1372-82. https://doi.org/10.1002/ It.23958

PMid:25046819

27. Boucher J, Kleinridders A, Kahn CR. Insulin receptor signaling in normal and insulin-resistant states. Cold Spring Harb Perspect Biol. 2014;6(1):a009191. https://doi.org/10.1101/cshperspect. a009191

PMid:24384568

28. Favaretto F, Milan G, Collin GB, Marshall JD, Stasi F, Maffei P, et al. GLUT4 defects in adipose tissue are early signs of metabolic alterations in Alms1GT/GT, a mouse model for obesity and insulin resistance. PLoS One. 2014;9(10):e109540. https:// doi.org/10.1371/journal.pone.0109540

PMid:25299671

29. Yeop Han C, Kargi AY, Omer M, Chan CK, Wabitsch M, et al. Differential effect of saturated and unsaturated free fatty acids on the generation of monocyte adhesion and chemotactic factors by adipocytes: Dissociation of adipocyte hypertrophy from inflammation. Diabetes. 2010;59(2):386-96. https://doi. org/10.2337/db09-0925

PMid:19934003

30. Jackson RM, Griesel BA, Gurley JM, Szweda LI, Olson AL. Glucose availability controls adipogenesis in mouse 3T3-L1 adipocytes via up-regulation of nicotinamide metabolism. J Biol Chem. 2017;292(45):18556-64. https://doi.org/10.1074/jbc. M117.791970

PMid:28916720

31. Magun R, Boone DL, Tsang BK, Sorisky A. The effect of adipocyte differentiation on the capacity of 3T3-L1 cells to undergo apoptosis in response to growth factor deprivation. Int J Obes Relat Metab Disord. 1998;22(6):567-71. https://doi. org/10.1038/sj.ijo.0800626

PMid:9665678

32. Feng H, YuL, Zhang G, Liu G, Yang C, Wang H, Song X. Regulation of autophagy-related protein and cell differentiation by high mobility group box 1 protein in adipocytes. Mediators Inflamm. 2016;2016:1936386. https://doi.org/10.1155/2016/1936386 PMid:27843198

33. Jarc E, Petan T. Lipid droplets and the management of cellular stress. Yale J Biol Med. 2019;92(3):435-52. PMid:31543707

34. Jo J, Gavrilova O, Pack S, Jou W, Mullen S, Sumner AE, et al Hypertrophy and/or hyperplasia: Dynamics of adipose tissue growth. PLoS Comput Biol. 2009;5(3):e1000324. https://doi. org/10.1371/journal.pcbi.1000324

PMid:19325873

35. Himms-Hagen J, Melnyk A, Zingaretti MC, Ceresi E, Barbatelli G, Cinti S. Multilocular fat cells in WAT of CL-316243treated rats derive directly from white adipocytes. Am J Physiol Cell Physiol. 2000;279(3):C670-81. https://doi.org/10.1152/ ajpcell.2000.279.3.C670 PMid: 10942717

36. Strieleman PJ, Schalinske KL, Shrago E. Fatty acid activation of the reconstituted brown adipose tissue mitochondria uncoupling protein. J Biol Chem. 1985;260(25):13402-5.

PMid:4055740

37. Nishimoto Y, Tamori Y. CIDE family-mediated unique lipid droplet morphology in white adipose tissue and brown adipose tissue determines the adipocyte energy metabolism. J Atheroscler Thromb. 2017;24(10):989-98. https://doi.org/10.5551/jat. rv17011

PMid:28883211

38. Rockenfeller P, Ring J, Muschett V, Beranek A, Buettner S, Carmona-Gutierrez D, et al. Fatty acids trigger mitochondriondependent necrosis. Cell Cycle. 2010;9(14):2836-42. https:// doi.org/10.4161/cc.9.14.12267

PMid:20647757

39. Yu J, Zhang S, Cui L, Wang W, Na H, Zhu X, et al. Lipid droplet remodeling and interaction with mitochondria in mouse brown adipose tissue during cold treatment. Biochim Biophys Acta. 2015;1853(5):918-28. https://doi.org/10.1016/j. bbamcr.2015.01.020

PMid:25655664

40. Park S, Oh TS, Kim S, Kim EK. Palmitate-induced autophagy liberates monounsaturated fatty acids and increases Agrp expression in hypothalamic cells. Anim Cells Syst (Seoul). 2019;23(6):384-91. https://doi.org/10.1080/19768354.2019.169 6407

PMid:31853375

41. Nakajima $S$, Nishimoto $\mathrm{Y}$, Tateya $\mathrm{S}$, Iwahashi $\mathrm{Y}$, Okamatsu-Ogura $Y$, Saito M, et al. Fat-specific protein $27 \alpha$ inhibits autophagy-dependent lipid droplet breakdown in white adipocytes. J Diabetes Investig. 2019;10(6):1419-29. https:// doi.org/10.1111/jdi.13050 PMid:30927519

42. Schulze RJ, Sathyanarayan A, Mashek DG. Breaking fat: The regulation and mechanisms of lipophagy. Biochim Biophys Acta Mol Cell Biol Lipids. 2017;1862(10):1178-87. https://doi. org/10.1016/j.bbalip.2017.06.008 PMid:28642194

43. Maruyama H, Kiyono S, Kondo T, Sekimoto T, Yokosuka O. Palmitate-induced regulation of PPAR $\gamma$ via PGC1 $\alpha$ A mechanism for lipid accumulation in the liver in nonalcoholic fatty liver disease. Int J Med Sci. 2016;13(3):169-78. https://doi. org/10.7150/ijms.13581

PMid:26941577

Author Query???

AQ1 ;Kindly provide department 